\title{
Perspektif Implementasi Total Quality Management (TQM) Pada Institusi Pendidikan Tinggi
}

Slamet

Penulis adalah dosen Fakultas Ekonomi dan

Kepala Laboratorium Komputer Universitas Isiam Indonesia Sudan Malang

\begin{abstract}
Change of environment having the character of turbulen, bringing impact to institution management, not escape education, hence expected have to can alter orientation having the character of proaktif as influence of change of world recognized with globalization. Institution higher education represent mediator between society as society and input as service user or higher education. Therefore higher education have to pay attention importance of society as according to outcome with requirement of student, society and pay attention the quality of education with Total Quality Management (TQM) approach which during the time used many in the world of business.

Reason of ht base is that education institution output will compete in labor market at free market which have been started 2003 year the, where society we will come in contact with world cleft people. Therefore require to be drawn up by human resource to anticipate the emulation, passing going concern process (improvement continous).

$T Q M$ approach represent approach for the management to build a system which focusing to one who aim to to increase the quality of product (yealded jasa) on an on going basis to reach satisfaction of society. This system work by horizontal entangling all human resource, from top to bottom, extend from upstream to downstream, incluiding input link and of output and also customer.
\end{abstract}

Ulul Albab, Vol. 4 No. 1, 2002 


\section{A. Pengantar}

Kita sekarang telah melangkah dan mengarungi gelombang abad baru yang sering disebut masa madani, millennium, atau sebutan lain yang diawali dengan globalisasi ekonomi yang melanda semua negara di dunia. Namun tidak dapat kita pungkiri globalisasi tidak hanya bertumpu atau berpusat pada persoalan-persoalan ekonomi, tetapi akan terjadi juga di lembaga pendidikan atau kita sebut dengan globalisasi pendidikan. Dalam sejarah umat manusia, belum pernah pergantian abad, ditandai dengan globalisasi ekonomi yang sedemikian pesat, serentak, dan pervasive. Hal ini akan membawa dampak terhadap manajemen linstitusi pendidikan untuk mengubah orientasi pada lingkungan yang turbulen. Dimana manajemen harus bersifat proaktif dengan perubahan lingkungan yang terjadi, dan tidak boleh berlagak statis - akulah yang terbaik.

Globalisasi yang melanda negara kita secara cepat membuka cakrawala baru bagi manajemen di Indonesia, tidak luput manajemen institusi pendidikan tinggi di negara ini, yang semula hanya tertuju pada lingkungan domestik (domestic environment) dan harus menjadi terbuka ke lingkungan global (global environment). Keadaan ini memaksa manajemen untuk melakukan rekayasa ulang terhadap manajemen yang selama ini digunakan untuk menghasilkan produk (product is good or service). Di dalam lingkungan global seperti sekarang ini, masyarakat telah mengalami perubahan pesat, baik dalam tuntutan mereka maupun cara mereka memenuhi tuntutannya. Oleh karena itu, untuk dapat bertahan hidup dan berkembang dalam lingkungan yang telah berubah ini, manajemen perlu mengubah paradigma agar sikap dan tindakan menjadi efektif.

Sebagaimana yang digambarkan oleh Tampubolon ${ }^{1}$ ada tiga tantangan utama dalam abad ini, yaitu (1) Heterogenitas Indonesia, (2) Perkembangan Masyarakat, dan (3) Pengaruh Proses Perkembangan Sosial Ekonomi. Dari sudut heterogenitas dapat dilihat dari sudut pandang kondisi geografis, kependudukan, bahasa, budaya, agama, kepercayaan, tingkat kemajuan pendidikan, dan kehidupan ekonomi. Sedangkan perkembangan masyarakat dinegara ini telah mengalami perubahan yang sangat cepat dan mengalami beberapa tahap, antara lain : masyarakat pra industri (traditional agriculture of society), masyarakat industri (modern society), dan masyarakat pascaindustri (information society). Sementara dari sisi

Ulul Albab, Vol. 4 No. 1, 2002 
perkembangan sosial ekonomi (economic social) ada empat proses, yaitu globalisasi, industrialisasi, asianisasi, dan sistem informasi canggih.

Era ini ditandai dengan meningkatnya proses pluralisme, yang menjadikan pusat tidak dapat lagi mampu mengendalikan semua urusan. Era ini menjadikan lingkungan yang turbulen. Pemusatan pengambilan keputusan ditingkat pusat tidak lagi efektif, dengan semakin turbulennya lingkungan memerlukan kecepatan respon terhadap setiap perubahan yang terjadi. Kondisi ini dapat dilakukan jika organisasi didesentraslisasi sedemikian rupa sehingga wewenang pengambilan keputusan berada di pimpinan yang dekat dengan lingkungan yang dihadapinya. Dalam era ini masyarakat memegang kendali, manajemen harus mengubah jalan pikiran ke logika yang dipakai oleh masyarakat. Namun mengubah jalan pikiran bukan merupakan hal yang mudah dilakukan, karena orang memiliki kecenderungan untuk functional fixation. Hal ini nampaknya cocok dengan pikiran yang dikembangkan oleh Tampubolon ${ }^{2}$ sebagai kesimpulannya bahwa ada tiga gelombang masyarakat dalam menempuh atau memperoleh pendidikan khususnya jenjang pendidikan tinggi, yaitu Elitisme, populisme, dan integralisme. Pada gelombang elitisme, orang yang dapat menempuh pendidikan adalah masyarakat yang tergolong kelompok "the have". Populisme timbul dan berkembangan berkaitan dengan era modern society. Pada gelombang ini pertumbuhan ekonomi menjebabkan peningkatan pendapatan masyarakat. Dengan pendapatan yang semakin baik, sejalan dengan kesadaran akan persamaan hak dalam semua bidang kehidupan, maka tuntutan pendidikan menjadi hal yang urgen. Pada gelombang yang terakhir adalah bagaimana menggabungkan antara elitisme dan populisme, walaupun keduanya mempunyai kekurangan dan dampak di masyarakat, dan kita harus menyadari bahwa setiap masyarakat berhak memproleh pendidikan sesuai undangan-undang dasar pasal 33 Undang-Undang Dasar 1945. Dan saat ini sebagian besar masyarakat sadar akan kebutuhan pendidikan yang pada gilirannya untuk memperbaiki taraf hidup masyarakat yang bersangkutan. Akan tetapi yang menjadi titik perhatian bagi manajemen institusi pendidikan tinggi adalah kesesuaian outcome dengan kebutuhan mahasiswa, masyarakat, dan dunia kerja.

Oleh sebab itu untuk mewujudkan tuntutan masyarakat dalam lingkungan yang turbulen dan sekaligus menjawab tuntutan masyarakat dalam menempuh pendidikan saat ini, maka manajemen harus memperhatikan kualitas pendidikan. Tulisan ini bermaksud mengadopsi teori Total Quality Management (TQM) yang 
selama ini dikembangkan dan hanya dipahami oleh manajer-manajer dalam dunia bisnis, tapi bagaimana TQM juga bisa diterapkan dalam dunia pendidikan tinggi yang berkecimpung dalam proses meningkatkan kualitas sumber daya manusia, walaupun konsep TQM pada institusi pendidikan tinggi masih pro kontra, minimal menambah wacana berpikir secara kreatif.

\section{B. Keterkaitan Tenaga Kerja dengan Pembangunan Ekonomi.}

Untuk mendukung penerapan TQM dalam lembaga pendidikan tinggi, di awali dengan pembentukan kawasan perdagangan bebas atau yang kita kenal dengan AFTA (Asean Free Trade Area) yang - sudah dilaksanakan mulai tahun 2003 ini - memberikan kebebasan perdagangan regional di antara negara-nagara anggota ASEAN, terutama yang berkaitan dengan kebijakan pengurangan tariff di masing-masing negara. Keadaan ini menunjukkan indikasi bahwa dengan berlakunya AFTA akan terjadi persaingan ketat di antara negara-negara anggota ASEAN. Persaingan (competition) ini sangat berkaitan erat dengan sumber daya manusia yang dimiliki oleh suatu negara.

Dalam siklus pasar kerja dan pasar barang (labour market and goods market circle) angkatan kerja baru merupakan keluaran (outcome) dari system pendidikan. Selain itu sumber angkatan kerja baru adalah bagian dari penduduk lain yang tidak bersekolah, tetapi masuk pasar kerja. Tambahan orang yang bekerja ditentukan oleh kemampuan pertumbuhan ekonomi dan proses produksi. Dengan demikian agar proses transisi antara pendidikan dan pekerjaan berjalan dengan mulus, maka penyusunan system pembinaan sumber daya manusia juga perlu mengacu pada system pembangunan ekonomi dan penyerapan tenaga kerja. Pada transisi ini perlu diamati secara terus menerus hal-hal yang terjadi di pasar kerja tempat dimana terjadi pertemuan antara persediaan dan kebutuhan tenaga kerja yang merupakan refleksi keberhasilan perpaduan antara system pendidikan dan system ekonomi.

Transformasi ekonomi seperti yang dikemukakan di atas perlu didukung dengan tersedianya sumber daya manusia yang mempunyai kualitas dan daya saing tinggi. Berarti kualitas sumber daya manusia perlu ditingkatkan sesuai dengan kebutuhan dunia kerja. Peningkatan kualifikasi sumber daya manusia dimaksud adalah bukan 
peningkatan kualitas ketrampilan yang dimiliki tetapi lebih kepada peningkatan kualitas pengetahuan (knowledge) termasuk peningkatan pengetahuan interdisplin dan kemampuan (abilities) sumber daya manusia itu sendiri. Sumber daya manusia yang mempunyai kualitas dan daya saing tinggi membutuhkan pengembangan dalam hal inisiatif (initiative), kreatifitas (creativity), perdaya diri (self-confidence), tanggungjawab (responbility), perpindahan (mobility), mudah menyesuaikan (flexible), siap untuk menerima pengetahuan baru (readiness to learn), sadar terhadap kualitas (quality consciousness), kemampuan untuk bekerjasama (ability to cooperate), mempunyai kemampuan untuk bermusyawarah untuk sepakat dan loyal terhadap organisasi (compromise and loyality) dapat menyiapkan diri untuk mengambil keputusan (prepared for decision making), dapat mengerti suatu system yang kompleks (understanding of complex systems), mempunyai kemampuan untuk berkomunikasi (communication skill) dan mempunuai spirit untuk bekerja secara kelompok (team spirit). ${ }^{3}$

Kualifikasi sumber daya manusia di atas sangat berkaitan dengan dengan. institusi pendidikan sebagai salah satu institusi penghasil sumber daya manusia terdidik yang masuk ke pasar kerja. Institusi pendidikan harus memperhatikan proses pendidikan untuk dapat menghasilkan sumber daya manusia yang mempunyai daya saing tinggi di masyarakat. Menghadapi era globalisasi ini, dunia pendidikan harus banyak melihat perkembangan yang terjadi di dunia luar - pengguna outcome. Dengan demikian kurikulum yang digunakan paling tidak harus dapat mencerminkan apa yang diinginkan oleh dunia kerja atau yang kita kenal curriculum based compentens. Kurikulum merupakan alat transportasi sistem pendidikan dirasa perlu dilaksanakan perombakan yang mengarah kepada tuntutan mahasiswa, masyarakat, dan dunia kerja.

\section{Filosofi Total Quality Manajemen}

Pada awal decade 1990-an kita mulai melihat perubahan-perubahan dalam filosofi manajemen mengenai bagaimana bekerja dan membuat pertimbangan. Mulai ada pergerakan ke arah menajemen berdasarkan metodologi daripada sekedar manajemen berdasarkan tujuan. Singkatnya, ini berarti para manajer lebih memusatkan perhatian pada perbaikan cara-cara pekerjaan diselesaikan, bukan sekedar perhatian pada apa yang diselesaikan. Lingkungan organisasi mengalami

Ulul Albab, Vol. 4 No. 1, 2002 
banyak perubahan dramatis dalam dua dasawarsa terakhir. Dinamika yang betlangsung cepat dan terus-menerus ini memunculkan banyak konsep, pendekatan, dan strategi manajerial untuk meresponnya. Menarik untuk ditelaah, ternyata ada dua macam pola penamaan di antara konsep, pendekatan, maupun strategi yang berhasil meraih "popularitas" tinggi. ${ }^{4}$

Dalam lingkungan baru ini, kita perlu memiliki system pemrosesan, yang memungkinkan fungsi-sungsi yang ada untuk saling mendukung secara efisien. Semua bagian dalam organisasi harus saling membantu pada tingkat yang sama tanpa harus naik dan turun dari satu bagian ke bagian lain guna menyampaikan pekerjaan Pendekatan tersebut harus memandang semua aktivitas sebagai prosesproses yang saling terkait. Dalam dunia praktik kualitas, system operasi yang berbasis matriks perlu ada yang menghubungkan satu bagian organisasi ke bagian lain, dan sampai tingkat tertentu, teknologi memberikan konsistensi dan komunikasi yang dibutuhkan.

Ketika hal tersebut kita lakukan, maka kualitas secara berangsur-angsur akan membaik, dan kita sepakat bahwa kualitas ditentukan oleh pengguna produk yaitu masyarakat. Namun demikian organisasi yang satu dengan yang lain memberikan tanggapan yang berbeda-beda terhadap kualitas khususnya tentang standar kualitas itu sendiri. Oleh sebab itu kita harus memahami siapa yang menjadi segmentasi atau bagian masyarakat yang menggunakan produk kita, dalam hal ini bukan sekedar pengguna namun juga sector-sektor lain.

Apa sebenarnya kualitas itu? Banyak definisi tentang kualitas, tergantung siapa yang memahami dan organisasi mana yang mengembangkan. W. Edwards Deming, seorang guru terkenal dibidang kualitas, menyebutkan "perbaikan kerkesinambungan (continous improvement)". ${ }^{5}$ Sementara Goetsh \& Davis (1994) dalam Tjiptono, merumuskan konsep holistic menganai kualitas sebagai kondisi dinamis yang berhubungan dengan produk, manusia, proses, dan lingkungan yang memenuhi atau melebihi harapan pelanggan.

Kualitas adalah paduan sifat-sifat produk yang menunjukkan kemampuannya dalam memenuhi kebutuhan pelanggan langsung atau tidak langsung, baik kebutuhan yang dinyatakan maupun yang tersirat masa kini dan masa depan. ${ }^{6}$

Kualitas (quality) biasanya berkenaan dengan sifat kebaikan, maka dapat dipahami bahwa makna itu berkaitan dengan aspek nilai, yang berbeda dari suatu 
kebudayaan ke kebudayaan lainya, bahkan dari individu ke individu lainnya. Pemahaman tentang mutu juga dipengaruhi oleh tingkat kemajuan pendidikan dan ekonomi individu serta masyarakat. Bagi orang dan masyarakat yang belum berpendidikan, terutama di pedesaan, misalnya, makanan bermutu adalah yang enak (lezat) rasanya dan dapat membuat kenyang. Tetapi bagi orang dan masyarakat yang berpendidikan, terutama di perkotaan, makanan bermutu adalah yang bergizi, sesuai dengan ukuran kesehatan. Jadi kualitas secara singkat dapat dilihat dari berbagai aspek dan tergantung siapa yang memandang.

Ditilik sejarahnya, secara garis besar ada tiga tahap perkembangan konsep kualitas. ${ }^{7}$ Tahap yang paling awal adalah era crafismanship, di mana individu yang sangat terampil mengerjakan semua tugas yang dibutuhkan untuk menghasilkan produk yang berkualitas. Dengan demikian pengendali kualitas bertumpuk satu orang atau yang disebut orang 'superman'. Namun pendekatan ini sudah ditinggalkan orang, sesuai dengan perkembangan studi waktu dan gerak. Kedua pendekatan tradisional "ofter-the fact" yang sangat kental diwarnai dengan inspeksi tidak lagi memadai. Hasil inspeksi tidak lebih dari sekedar menyisihkan komponen yang jelek. Pendekatan ini tidak menyelesaikan masalah, karena tanggungjawab kualitas dibebankan semata-mata pada departemen kualitas, Ketiga, pendekatan $3 \mathrm{~K}$ (komunikasi, Koordinasi, dan Kerjasama) akibat pemisahan secara kaku antara think dan act. Kenyataan ini mendorong munculnya pendekatan kualitas total (Total Quality Approach) yang dalam pekembangannya lebih dikenal dengan istilah Total Quality Manajemen (TQM).

Total Quality Management (TQM) adalah suatu system manajemen yang berfokus kepada orang yang bertujuan untuk meningkatkan secara berkelanjutan kepuasan masyarakat (customer) pada tingkat biaya sesungguhnya yang secara berkelanjutan terus menurun. ${ }^{8}$ TQM merupakan pendekatan system secara menyeluruh (bukan suatu bidang atau program terpisah), dan merupakan bagian terpadu strategi tingkat tinggi. Sistem ini bekerja secara horosintal menembus fungsi, melibatkan semua sumber daya manusia, dari atas sampai bawah, meluas ke hulu dan ke hilir, mencakup mata rantai input dan output serta pengguna.

Robbins $^{9}$ mendefinsikan TQM ada lima point, yaitu : (1) Intense focus on the customer. The customer includes not only outsiders who buy the organization's products or services but also internal customer (such as shiping or accounts payable personnel) who interact with and serve others in the organization; (2) Concern for 
continous improvement. TQM is a commitment to never being satisfied. "Very good" is not good enough. Quality can always be improved; (3) Improvement in the quality of everything the organization does. TQM uses a very broad definition of quality. It relates not only to the final product but also to how the organization handles deliveries, how rapidly it responds to complaints, how politely the phones are answered, and the like; (4) Accurate measurement. TQM uses statistical techniques to measure every critical performance variable in the organization's operations. These performance variables are then compared against standards or benchmarks to indentify problems, the problems are traced to their roots, and the causes are eliminated; and (5) Empowerment of employees. TQM involves the people on the line in the improvement process. Teams are widely used in TQM programs as empowerment vehicles for finding and solving problems.

Oleh karena itu, untuk memperbaiki kualitas berkelanjutan atau yang disebut dengan steps kualitas, ${ }^{10}$ dia menyarankan adanya : (1) Komitmen manajemen (Management Commitment); (2) Tim Perbaikan Mutu (Quality Improvement Team); (3) Ukuran Mutu (Quality Measurement); (4) Biaya evaluasi (Cost of Quality Evaluation); (5) Kesadaran Mutu (Quality Awareness); (6) Tindakan Perbaikan (Corrective Action); (7) Pelatihan (Training); (8) Hari tanpa cacat (Zero Defects Day); (9) Penetapan Sasaran (Goal Setting); (10) Penghilangan penyebab Kesalahan (Error Causes Removal); (11) Pengakuan (Recognition); (12) Dewan Mutu (Quality Council); dan (13) Lakukan Lagi (Do it over again).

Dalam manajemen tradisional umumnya, ada tiga fungsi pokok manajemen, yaitu Quality Planning, Quality Control, dan Quality Improvement. Dimana Quality Planning meliputi : (1) mengindentifikasi dan menentukan pelanggan, (2) mengidentifikasi dan menentukan kebutuhan pelanggan, (3) merencanakan produk yang sifat-sifatnya sesuai dengan kebutuhan pelanggan, (4) menyusun dan menentukan system dan proses-proses yang dapat menghasilkan produk yang direncanakan, (5) menjabarkan seluruh proses dalam system yang ditentukan menjadi kegiatan-kegiatan dan langkah-langkah operasional (teknis). Kedua, Quality Control, yang meliputi : (1) melaksanakan rencana mutu yang ditetapkan sesuai dengan langkah dan prosedur teknis yang ditentukan, (2) mengadakan evaluasi terhadap semua proses/langkah selama proses itu berlangsung dan mencatat kesalahan/kelemahan yang terjadi, (3) melakukan perbaikan pada kesalahan/ kelemahan yang terjadi berdasarkan hasil evaluasi, selama proses masih 
berlangsung, (4) melakukan evaluasi akhir terhadap proses dan produk, serta menginventarisasi kekuatan, kelemahan dan hal-hal baru untuk peningkatan mutu selanjutnya. Ketiga, Quality Improvement, yang meliputi : Menganalisis hasil evaluasi yang sudah dilakukan pada pengendalian mutu yang sudah terlaksana dan menentukan kelemahan-kelemahannya, (2) meneliti kembali kebutuhan pelanggan, (3) menyusun rencana peningkatan mutu berdasarkan data-data kelemahan dan kebutuhan pelanggan, (4) mempersiapkan semua sarana dan prasarana serta SDM yang diperlukan, (5) membentuk tim kerjasama dan memberdayakan agar mampu melaksanakan peningkatan mutu, dan (6) melaksanakan rencana peningkatan mutu dengan system dan proses seperti pengendalian mutu. ${ }^{11}$

Oleh sebab itu, secara umum kualitas (quality) dapat dikembangkan dengan dua cara yaitu Macro Quality, yang bersifat strategis terutama pada produk yang mengandung sifat kebijakan strategis. Pada point ini dikembangkan oleh manajemen puncak sebagai pengambil kebijakan. Dan Micro Quality, menyangkut kualitas yang bersifat teknis yang dikembangkan atau dilakukan oleh manajemen operasional yang dapat menentukan kualitas teknis.

\section{Implementasi TQM dalam Manajemen Institusi Pendidikan Tinggi}

Berdasarkan GBHN 1993 TAP MPR No. IIMPR/1993 dan KPPT JP 19962005, bahwa Institusi Pendidikan adalah tempat meningkatkan kualitas manusia Indonesia, yaitu manusia yang beriman dan bertakwa terhadap Tuhan Yang Maha Esa, berbudi pekerti luhur, berkepribadian, mandiri, maju tangguh, cerdas, kreatif, terampil, berdisiplin, beretos kerja, professional, bertanggung jawab, dan produktif serta sehat jasmani dan rohani. Juga harus menumbuhkan jiwa patriotic dan mempertebal rasa cinta tanah air, meningkatkan semangat kebangsaan dan kesetiakawanan social serta kesadaran pada sejarah bangsa dan sikap menghargai jasa para pahlawan serta berorientansi masa depan. Dan menumbuhkan iklim belajar dan mengajar yang dapat menumbuhkan rasa percara diri dan budaya belajar di kalangan masyarakat, agar tumbuh sikap dan perilaku yang kreatif, inovatif, dan keinginan untuk maju.

Tujuan Strategis Institusi Pendidikan Tinggi, antara lain : (1) menyiapkan mahasiswa menjadi anggota masyarakat yang memiliki kemampuan akademik dan/ 
atau professional, serta kemampuan kepemimpinan yang tanggap terhadap kebutuhan pembangunan serta pengembangan ilmu pengetahuan dan teknologi, berjiwa penuh pengabdian dan memiliki rasa tanggungjawab yang besar terhadap masa depan bangsa dan negara; (2) misi system pendidikan tinggi adalah untuk menyelenggarakan fungsi kelembagaan pendidikan tinggi berdasarkan wawasan, untuk : (a) menghasilan anggota masyarakat yang bertakwa terhadap Tuhan Yang Maha Esa, yang berakhlak tinggi, berbudaya Indonesia bersemangat ilmiah serta memiliki kemampuan akademik dan suatu professional dan sanggup berkinerja baik dilingkungan kerjanya; (b) menghasilkan ilmu pengetahuan dan teknologi baru, menghasilkan peneliti dan pemikir, serta memutakhirkan pengetahuan dan kemampuan agar system berdaya dalam menghimpun, mengalihkan, menyebarkan, menafsirkan, dan menerapkan ilmu pengetahuan dan teknologi yang telah ada bagi kemajuan dan kesejahteraan masyarakat; (3) menyebarkan hasil penelitian terapan, kajian tindak, maupun pakai teknologi tepatguna, untuk dimanfaatkan dalam kegiatan produktif dan peningkatan mutu kehidupan masyarakat.

Sesungguhnya institusi pendidikan tinggi ibarat industri jasa - seperti rumah sakit, hotel, biro perjalanan, konsultan, atau yang lain - yang bergerak dalam pelayanan (jasa) yaitu pelayanan pendidikan yang bertujuan untuk peningkatan sumber daya manusia sesuai kebutuhan masyarakat. Menurut Tampubolon, ${ }^{12}$ Produk Pendidikan Tinggi adalah jasa kependidikan tinggi yang terdiri atas jasa kurikuler, jasa penelitian, jasa pengabdian pada masyarakat, jasa administrasi, dan jasa ekstrakuliler, dan lulusan itu sendiri. Dalam hubungan dengan pelayanan (jasa), sumber daya manusia industri jasa sangat menentukan, di samping keahlian dan ketrampilan (skills) serta professionalisme. Lulusan merupakan produk akhir dan indicator kualitas dari pendidikan tinggi yang bersangkutan. Walaupun lulusan dipahami sebagai produk parsial, karena sesungguhnya mahasiswa berkualitas tidak hanya dari lembaga pendidikan tinggi itu saja, melainkan juga karena adanya potensi dan usaha sendiri. Selain itu, pengaruh lingkungan, dukungan orang tua, informasi, dan teknologi sangat berpengaruh terhadap lulusan. Meskipun, banyak variable yang mempengaruhi kualitas lulusan, pendidikan tinggi mempunyai andil dan tanggungjawab yang cukup besar terhadap kualitas tersebut. Lulusan merupakan produk yang sangat penting, bahkan dapat dikatakan tujuan utama pendidikan tinggi, karena bersifat generatif dan aplikatif. Dikatakan generatif, karena melalui lulusanlah jasa-jasa pendidikan tinggi disebarkan luaskan, dikembangkan, serta dilestarikan 
dalam dunia kerja dan masyarakat. Dikatakan aplikatif, karena dengan lulusanlah yang mengaplikasikan jasa-jasa pendidikan tinggi ke dalam dunia kerja, sehingga hasilnya dapat dinikmati oleh individu dan masyarakat, sehingga jasa-jasa itu juga berkembang, dan mutu kehidupan meningkat.

Oleh sebab itu lingkungan ke depan bersifat turbulen dan AFTA 2003 yang tidak hanya berkutat pada persoalan ekonomi, namun juga berpengaruh terhadap pendidikan, bisa jadi di Malang akan muncul institusi pendidikan tinggi yang bertaraf internasional, dan sekarang sudah banyak pendidikan tinggi dengan sebutan kelas internasional. Maka untuk mengimbangi kondisi di atas, pendidikan tinggi - tidak terlepas itu pendidikan tinggi bermerk negeri - harus memperhatikan kualitas lulusan (outcome) dengan jalan menerapkan Total Quality Management pada Pendidikan Tinggi (TQMPT). TQMPT ini merupakan proses berkelanjutan yang tidak dapat dikerjakan secara parsial, namun secara simultan, mulai perencanaan hingga evaluasi, evaluasi merupakan bahan perencanaan, dan seterusnya, dengan tetap memperhatikan kebutuhan pelanggan - mahasiswa dan dunia kerja.

Untuk dapat menerapkan TQMPT harus memperhatikan pilar TQM dalam sebuah organisasi, yaitu produk, proses, organisasi, pemimpin, dan komitmen, ${ }^{13}$ sebagaimana gambar berikut ini :

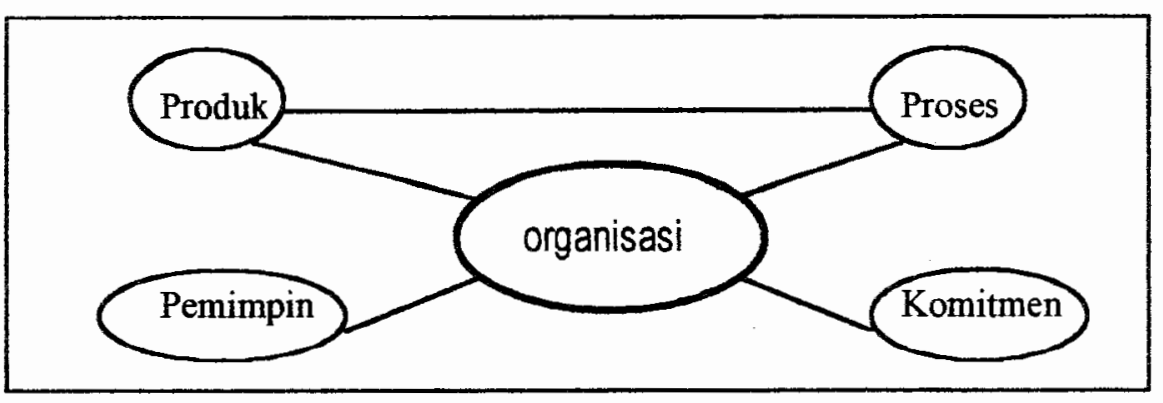

Menurut Herbert ${ }^{14}$ ada empat bidang utama dalam perguruan tinggi yang dapat mengadopsi prinsip-prinsip TQM. Pertama penerapan TQM untuk meningkatkan fungsi-fungsi administrasi dan operasi secara keseluruhan. Kedua mengintegrasikan TQM dengan kurikulum. Ketiga, penggunaan TQM dalam metode pengajaran di kelas. Dan keempat, menggunakan TQM untuk mengelola aktivitas riset. Berdasarkan data yang dikumpulkan oleh Quality Progress tahun 1992 institusi pendidikan tinggi di Amerika Serikat terdapat 220 institusi yang

Ulul Albab, Vol. 4 No. 1, 2002 
menerapkan TQM. ${ }^{15}$ Oleh karena itu, kehadiran TQMPT akan berdampak pada perubahan manajemen konvensional yang terdapat pada institusi pendidikan tinggi, yakni berkenaan dengan dimensi kualitas, focus pada pelanggan, kepemimpinan, perbaikan berkesinambungan, manajemen SDM, dan manajemen berdasarkan fakta.

Sehubungan dengan pendidikan tinggi adalah industri jasa pelayanan, maka perlu dikembangkan nilai, sikap dan sifat saling melayani yang baik, sehingga pelanggan merasa puas. Saling melayani bukan berarti selalu melayani pelanggan, yakni mahasiswa, tetapi pelanggan juga melayani pelayan. Karena pelanggan memberikan imbalan tertentu berupa pembayaran, kesepakatan, kepatuhan dan ketaatan, sehingga ada rasa saling membutuhkan sebagaimana yang bagan berikut: ${ }^{16}$

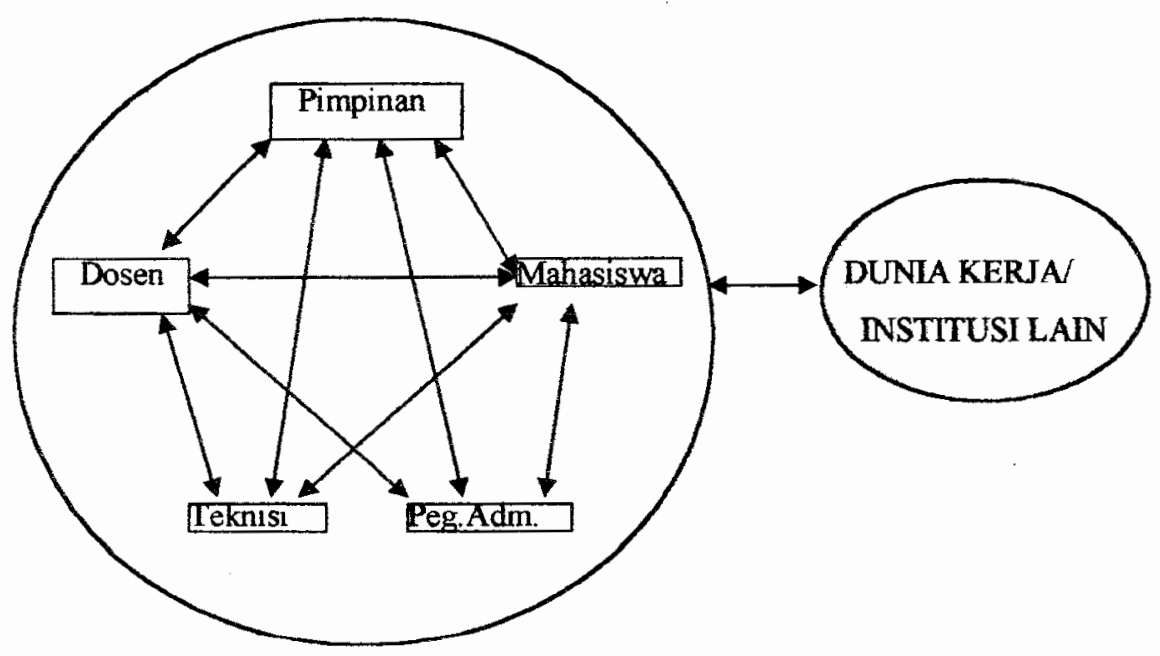

Agar dapat meningkatkan kualitas dengan penerapan TQMPT, Lewis dan Smith, ${ }^{17}$ memberikan kontribusi pemikiran kualitas terhadap institusi pendidikan tinggi apa yang disebut dengan Penyempurnaan Kualitas Berkesinambungan dalam Pendidikan Tinggi, sebagai bagan berikut: 


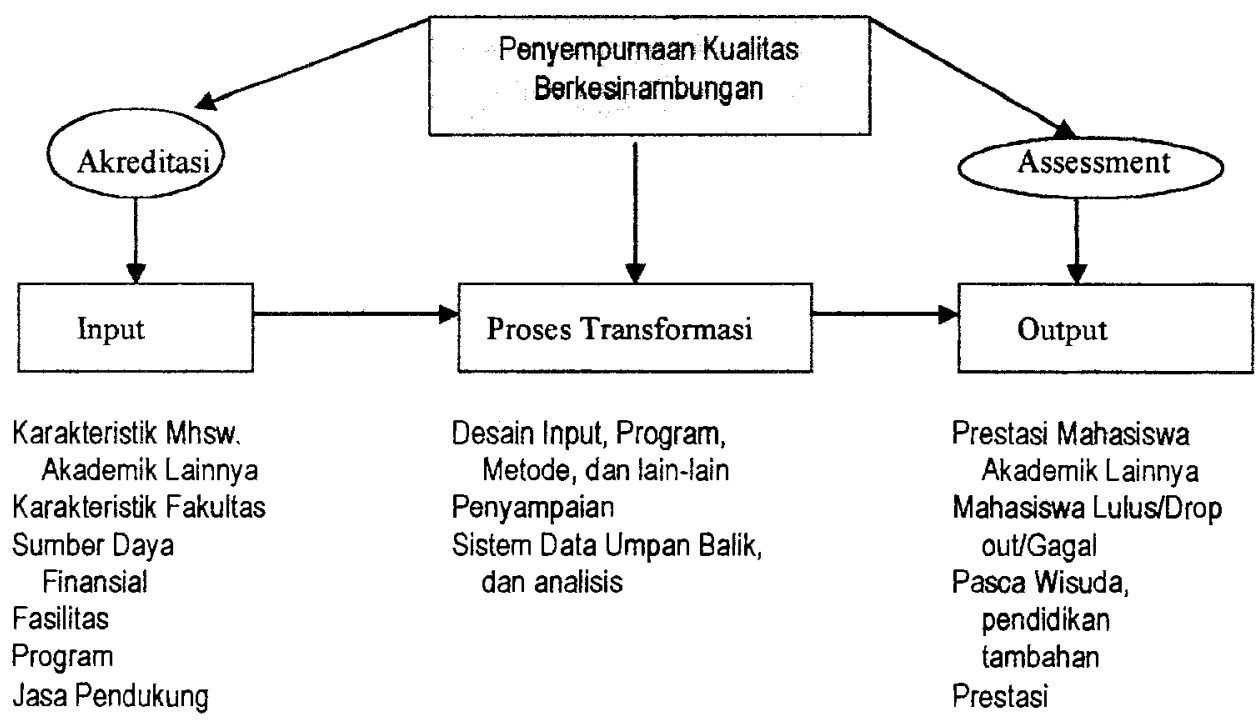

Sehingga dapat disimpulkan bahwa, upaya perbaikan kualitas secara berkesinambungan dalam pendidikan tinggi harus menggunakan pendekatan system terbuka atas fungsi pendidikan tinggi - student learning. Dari bagan dapat dilihat ada tiga komponen besar, yaitu Input, Proses Transformasi, dan Output. Namun ada yang cukup penting menurut hemat penulis selain ketiga variable tersebut yaitu Kelompok Pengembang Kualitas (Quality Improvement Team Works).

\section{Masukan (input) pendidikan tinggi}

Masukan dalam dunia bisnis merupakan hal yang paling vital, oleh sebab itu institusi pendidikan dalam hal masukan harus memperhatikan secara sungguhsungguh, karena masukkan sangat mempengaruhi proses yang tarap selanjutnya pada hasil yang tidak memuaskan. Input dalam institusi pendidikan tinggi yang sangat vital adalah input Sumber Daya Manusia - dosen, staf administrasi, dan teknisi, serta calon mahasiswa, disamping sumber daya yang lain. Untuk mendukung penerapan TQMPT, proses input dosen, teknisi, dan staf administrasi harus berangkat dari job analysis - gambaran pekerjaan yang dibutuhkan - dan job spesifikasi 
- gambar kualifikasi orang yang akan mengerjakan pekerjaan. Job analysis mengindentifikasi kebutuhan akan dosen ekonomi manajemen, dengan kualifikasi S-2, misalnya, namun yang diterima adalah sarjana S-2 ekonomi pertanian. Atau membutuhkan staf administrasi dengan kualifikasi pendidikan SMU, disiplin, professional, loyal, mampu mengoperasikan komputer, taat, rajin, dan tekun. Namun yang diterima sarjana hukum yang tidak menggambarkan dari job spesifikasi, kalau ini yang terjadi, sama sekali tidak mendukung proses penerapan TQMPT. Dalam hal ini harus memperhatikan job analysis dan job spesifikasi dalam proses seleksi SDM insititusi pendidikan tinggi.

Seleksi calon mahasiswa merupakan suatu system yang harus mempunyai landasan yang cukup dipandang dari segi akademik, ekonomi, pendidikan, maupun psiko-sosial. Karena itu suatu system penerimaan mahasiswa baru harus mempertimbangkan empat hal: ${ }^{18}$ (a) kecermatan prediksi (prediction effectivenss), (b) efisien ekonomik (economic efficient), (c) insentif belajar-mengajar (teachinglearning incentive), dan (d) keadilan (equity). Kecermatan prediksi menunjukkan kepada seberapa akurat system seleksi itu dapat membedakan calon-calon yang probabilitasnya berhasil besar dari mereka yang probabilitas kecil. Seberapa tepat keputusan seleksi menerima calon-calon yang berpotensi dan menolak calon-calon yang berpotensi rendah. Efisiensi ekonomi menunjukkan persoalan social benefit dan cost, sementara insentif belajar-mengajar menunjukkan kepada bagaimana system seleksi calon mahasiswa baru berpengaruh terhadap perilaku belajarmengajar di jenjang pendidikan di bawahnya. Pada umumnya orang menganggap sekolah menengah atas sebagai start untuk masuk pendidikan tinggi, hal ini akan berpengaruh terhadap pola kegiatan mengajar guru di jenjang SMU. Sedangkan keadilan menunjukkan kepada pemberian kesempatan yang sama untuk belajar di pendidikan tinggi kepada individu-individu yang memenuhi syarat.

\section{Proses Transformasi (Transformation Processing)}

Sistem dan proses produksi secara keseluruhan dan terpadu menjadi pusat perhatian dalam penentuan kualitas (quality). Karena seluruh system dan proses, serta produk harus memenuhi kebutuhan para pelanggan - mahasiswa, masyarakat, dan dunia kerja. Sebagai salah satu bentuk produk (jasa) yang melibatkan interaksi yang tinggi antara pelayan - institusi pendidikan tinggi - dengan pemakai jasa - 
mahasiswa -, terdapat lima dimenasi pokok yang menentukan kualitas institusi pendidikan tinggi, antar lain: ${ }^{19}$ Pertama, keandalan (reliability), yakni kemampuan memberikan pelayanan yang dijanjikan dengan segera/tepat waktu, akurat, dan memuaskan. Seperti, penawaran matakuliah (kurikulum) benar-benar sesuai dengan kebutuhan dan tuntutan ketrampilan, profesi, dan dunia kerja, jadwal kuliah dan ujian akurat, proses perkuliahan berlangsung lancar, penilaian yang fair, bimbingan dengan dosen wali terlaksana dengan baik, kegiatan mahasiswa, maupun aktivitas lainnya; Kedua, Daya tangkap (responsiveness), yaitu kemauan/kesediaan para staf untuk membantu para pelanggan dan memberikan pelayanan dengan tanggap. Membiarkan pelanggan menunggu untuk alasan yang tidak jelas bisa menimbulkan presepsi negatif terhadap kualitas. Dengan demikian rector, pembantur rector, dekan, pembandu dekan, ketua jurusan, dan para pejabat structural lainnya harus mudah ditemua; dosen juga harus gampang ditemui mahasiswa untuk keperluan konsultasi; proses belajar-mengajar hendaknya diupayakan interaktif dan memungkinkan para mahasiswa mengembangkan seluruh kapasitas, kreatifitas, dan kapabilitasnya; fasilitas pelayanan yang ada (perpustakaan, komputer, laboratorium, dan lain-lain) harus mudah diakses oleh setiap insan kampus, prosedur administrasi penerimaan mahasiswa baru harus sederhana, tidak birakratis. Dalam hal ini harus terjadi service failure - kemampuan untuk melakukan perbaikan secara cepat dan professional yang bisa menciptakan persepsi kualitas yang positif; Ketiga, jaminan (assurance), mencakup pengetahuan, kompetensi, kesopanan, respek terhadap pelanggan, dan sifat dapat dipercaya yang dimiliki para staf, bebas dari bahaya, resiko atau keraguraguan. Seluruh jajaran - dosen, asisten dosen, staf administrasi - harus benarbenar kompeten dibidangnya; Keempat, empati, meliputi kemudahan dalam melakukan hubungan, komunikasi yang baik, perhatian pribadi, dan memahami kebutuhan para pelanggan. Misalnya, dosen mengenal nama para mahasiswa yang menempuh matakuliah yang diampunya, dosen wali benar-benar berperan sebagaimana fungsinya, setiap dosen bisa dihubungi dengan mudah, baik diruang kerja, via telpon, maupun e-mail, dan sebagainya; Dan kelima, bukti langsung (tangibles), meliputi fasilitas fisik, perlengkapan, karyawan/dosen, dan sarana komunikasi. Misalnya berupa fasilitas komputer, perpustakaan, ruang kuliah yang representatif, ruang dosen, ruang seminar yang ada LCDnya, media perkuliahan OHP/LCD, kantin, tempat parkir yang aman dan nyaman, bookstore, jurnal ilmiah, sarana ibadah, olah raga, laboratorium, penampilan insan kampus yang meyakinkan.

Ulul Albab, Vol. 4 No. 1, 2002 
Senada dengan Fanndy bahwa kualitas akan dapat dilihat oleh pengguna masyarakat secara luas - apabila mempunyai image di mata masyarakat tentang atribut-atribut yang dimiliki oleh institusi pendidikan tinggi, menurut Tampubolon ${ }^{20}$ meliput:

Pertama, relevansi yaitu kesesuain dengan kebutuhan, misalnya kurikulum dan silabut menjawab kebutuhan mahasiswa dan dunia kerja, buku-buku diperpustakaan sesuai dengan jurusan atau tuntutan kurikulum, apakah keahlian dosen cukup relevan dengan program studi, lulusan nanti sesuai dengan dunia kerja; Kedua, Efisiensi yaitu kehematan dalam penggunaan sumber daya, menyangkut penggunaan anggaran yang direncanakan dan dipergunakan secara hemat dan tepat;

Ketiga, Efektifitas, yaitu kesesuaian perencanaan dengan hasil yang dicapai atau ketepatan system, metode, dan atau proses yang dipergunakan untuk menghasilkan jasa yang direncanakan. Misalnya metode penyajian materi kuliah cukup tepat sehingga mahasiswa memahaminya dengan mudah, prosedur administrasi tepat dan baik sehingga semua dapat berjalan dengan lancar dan cepat;

Keempat, akuntabilitas menyangkut perilaku pengelola, etika akademik, dan nilai-nilai budaya. Misalnya, peraturan atau kebijakan yang ditetapkan dapat dipertanggungjawabkan secara undang-undang, nilai-nilai yang dikembangkan apakah dapat dipercaya, dan lain sebagainya;

Kelima, kreativitas. Kemampuan untuk mengadakan inovasi, pembaharuan, atau menciptakan sesuatu yang sesuai dengan perkembangan zaman, termasuk kemampuan evaluasi diri, yang termasuk di dalamnya adalah kurikulum harus dilakukan pembaharuan sesuai perkembangan ilmu dan teknologi yang dibutuhkan dunia kerja, dosen harus melakukan penelitian dan melakukan pembaharuan materi yang didapat dari literature baru atau lapangan - penelitian, seminar, pengabdian, dan lain;

Keenam, Situasi yang menyenangkan dan memotivasi semua orang dalam melaksanakan tugas dengan senang hati, tulus, dan penuh semangat, hal ini menyangkut kebijakan yang diambil oleh pimpinan cukup adil atau tidak, sehingga tidak ada orang merasa dirugikan. Unsur-unsur pimpinan harus bersikap terbuka dan akrab terhadap semua elemen kampus, sehingga merasa bebas dan tidak tertekan; Ketujuh, Penampilan (performance) kampus dapat dilihat dari berbagai 
sudut, seperti lingkungan kampus harus selalu bersih, indah, dan harmonis yang membuat situasi yang menyenangkan serta kondusif untuk tempat belajar. Hal ini menyangkut, kebersihan kampus, penuh dengan tanaman-tanaman hias, staf selalu berpakaian rapi dan bersih, terutama dosen sewaktu mengajar dihadapan mahasiswa; Kedelapan, Empati, menunjukkan kemampuan para pengelola memberikan pelayanan sepenuh hati kepada semua pelanggan - mahasiswa dan masyarakat. Misalnya bagian receptionis dalam menerima tamu, apakah dengan penuh keramahan dan sopan dalam memberikan informasi, juga dosen apakah selalu memperhatikan dan melayani mahasiswa dengan sepenuh hati; Kesembilan, ketanggapan (responsiveness) yang menunjukkan kemampuan dalam memperhatikan dan membersikan respons terhadap keadaan serta kebutuhan pelanggan dengan cepat dan tepat; Kesepuluh, produktivitas (productivity) yang menunjukkan kemampuan untuk menghasilkan produk yang sesuai dengan pelanggan menurut rencana yang telah ditetapkan, baik secara kuantitatif maupun kualitatif, hal ini menyangkut hasil (outcome); Terakhir adalah kemampuan akademik, yaitu penguasaan mahasiswa atas bidang studi yang diambilnya.

Untuk merealisasikan kondisi sebagaimana disebutkan di atas, menuntut adanya transformasi berkesinambungan dan mendalam yang menuntut cara baru untuk berpikir dan berperilaku. Banyak variable penyebab yang mendorong orang untuk berubah, namun orang enggan melakukan perubahan, meskipun lingkungan menuntut perubahan. Hal ini disebabkan oleh ketidakmampuan orang dalam mengelola perubahan. Intitusi pendidikan tinggi merupakan wahana melakukan perubahan (change), karena di tempat inilah elemen kampus melakukan pembaharuan-pembaharuan yang dapat dilakukan melalui belajar dan belajar. Oleh karena itu , semua elemen kampus - rector, pembantu rector, dekan, pembantu dekan, ketua jurusan dan staf, pejabat structural, dan staf administrasi, serta teknisi - harus mempunyai keinginan untuk melakukan improvement secara berkelanjutan sesuai peran, fungsi, dan tanggungiawab masing-masing, sehingga perubahan tidak hanya bersumber dari rector sebagai pengendali institusi pendidikan tinggi. Setiap elemen kampus harus mempunyai pikiran sebagaimana yang disarankan oleh Hikmat Wijaya, diantaranya adalah Management Commitment, Zero Defect day, Error Causes Removal, dan Do it over again. Untuk melakukan transformasi setiap insane harus mempunyai KEINGINAN sebagaimana yang direkomendasi oleh Mulyadi ${ }^{21}$ transformasi dilaksanakan melalui siklus yang terdiri dari empat tahap, yaitu : Tahap pemicuan, tahap ketidakpastian, tahap transformasi, dan tahap rutinisasi. Keempat tahap ini dapat dimulai pada titik keinginan, sebagaimana bagan berikut :

Ulul Albab, Vol. 4 No. 1, 2002 


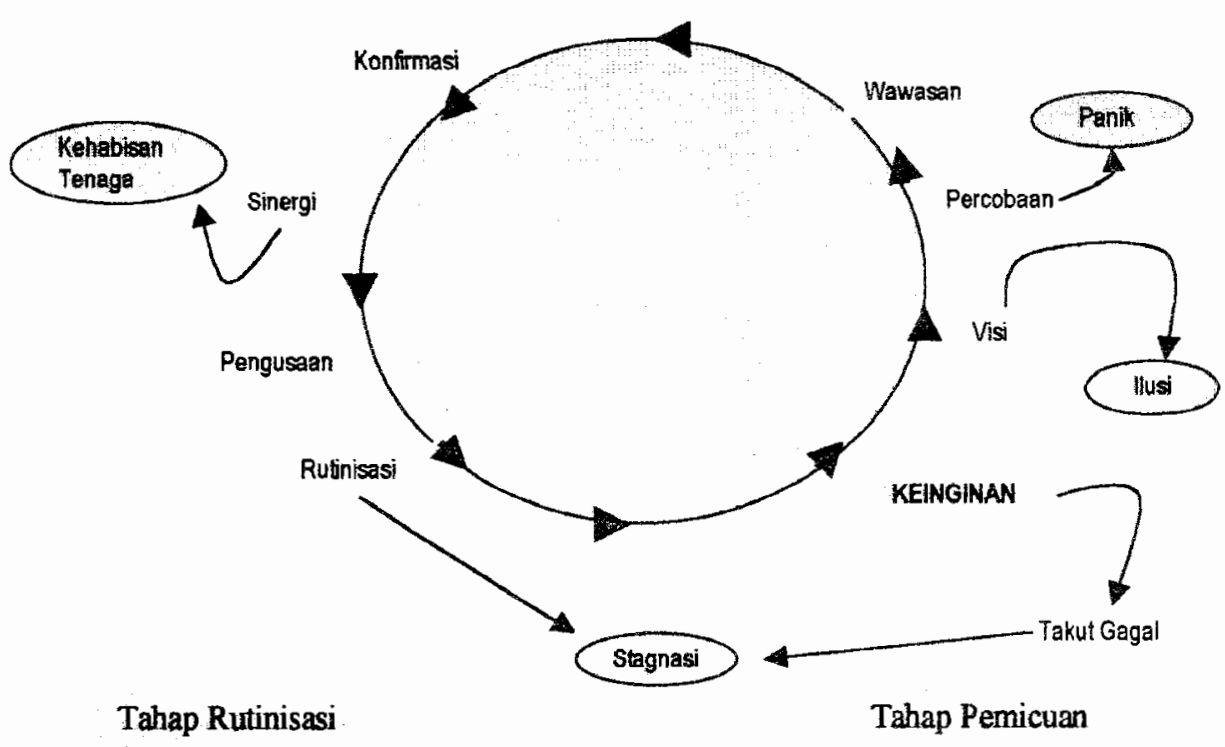

\section{Hasil (output)}

Sebagaimana disebutkan di atas, bahwa lulusan merupakan ukuran parsial dari produk sebuah institusi pendidikan tinggi, namun demikian parameter yang dapat digunakan adalah : seberapa besar penguasaan materi program studinya hal ini dapat dilihat dari ujian komprehensif dan skripsi, misalnya -; seberapa banyak (\%) yang mendapat nilai A, B, C, dan D; atau seberapa banyak (\%) IP yang dikategorikan baik; seberapa lama mahasiswa menyelesaikan studi; seberapa banyak lulusan dapat diterima oleh institusi pendidikan lain dalam melanjutkan studi; atau seberapa banyak lulusan dapat diterima oleh sector dunia kerja; serta adakah pelecehan atau penolakan terhadap lulusan oleh institusi lain. Oleh sebab itu, dalam meningkatkan kualitas pendidikan tidak boleh terlepas dari prinsip yaitu berfokus pada pelanggan, baik pelanggan secara langsung maupun pelanggan ticak iangsung. 


\section{Kelompok Pengembang Kualitas (Quality Improvement Team Works)}

Team pengembang mutu bertugas untuk membudayakan kualitas di seluruh pendidikan tinggi dan memberikan pemikiran serta saran tentang peningkatan kualitas berkesinambungan atau berkelanjutan. Team ini merupakan aspek yang penting dalam penarapanm TQMPT, karena dari situ pembudayaan kualitas dan pemikiran-pemikiran tentang peningkatan kualitas dapat berkembang dengan lebaih baik. Team pengembang ini berkewajiban memberikan saran tentang pembudayaan dan peningkatan kualitas kepada pimpinan atau manager organisasi.

Anggota team pengembang ini tidak boleh terlalu sedikit dan tidak boleh terlalu banyak berkisar antara $5 \mathrm{sd}$. 10 orang yang terdiri dari tim dosen dari berbagai disiplin ilmu, pimpinan fakultas, team pekerja teknis, dan mahasiswa. Anggota team harus menguasasi system dan cara perumusan dan penentuan masalah, analisis masalah untuk menemukan sumber dan sebab akar masalah, hingga merumuskan dan menentukan solusi masalah dalam rangka peningkatan kualitas. Disamping itu team ini bertugas mengembangkan kerjasama - bersama pembantu rector IV dengan dunia usaha atau lembaga-lembaga lain sebagai pengguna produk pendidikan tinggi.

\section{E. Kesimpulan}

Penciptaan kualitas total memang jauh lebih mudah diucapkan daripada dilaksanakan. Implementasi TQM memikat sekaligus mengikat, karena menuntut perubahan dan perombakan fundamental atas budaya organisasi tradisional. Di samping itu, komitmen dan totalitas yang dituntut dalam implementasi TQM harus sungguh-sungguh direalisasikan. Sumber daya manusia sebagai komponene vital dalam pendidikan tinggi juga patut mendapatkan perhatian dan perlakuan sebagaimana yang dituntut dalam TQM, kerja sama lintas fungsional, pemberdayaan dan keterlibatan semua staf, gaya manajemen partisipatif, tersedianya saluran komunikasi yang efektif, dan sebagainya.

Ulul Albab, Vol. 4 No. 1, 2002 


\section{Slamet}

\section{Endnotes}

1 Tampubolon, Daulat, P., Perguruan Tinggi Bermutu, Gramedia Pustaka Utama, Jakarta 2001, hal. 1 .

2 Tampubolon, Daulat, P., Ibid, hal. 11-15

${ }^{3}$ Yudo Swasono, dkk., Manajemen Dalam Era Globalisasi, Elex Media Komputindo, Jakarta, 1997.

4 Handoko, H. \& Tjiptono, F. Kepemimpinan Transformasional dan Manajemen Sumber Daya Manusia dalam Lingkungan Organisasi TQM, 1997.

5 James W. Cortada, dalam Handoko, Ibid hal : 8.

6 Tampubolon, 2001: 108

7 Tjiptono \& Diana, 1996

8 Mulyadi, 1998:10

9 Robbins, Stephens, Organizational Behavior, Concepts "Controversies" Applications, Eighth Edition, 1998.

10 Hikmat Wijaya, 1997

11 Juran, 1992

$12 \quad 2001: 71$

13 Creech, 1996 dalam Fandy, 1999

14 dalam Sarwono \& Sudarsono, 1997

is Lewis \& Smith, 1994

16 Tampubolon, 2001

17 dalam Tjiptono, 1999

18 Kompas, 1999

19 Fandy, 1999

20 Tampubolon, Op. Cit

21 Mulyadi, Total Quality Management, Universitas Gadjah Mada, Yogyakarta, 1998. 


\section{Bibliography}

Cortada, James, W., Total Quality Managemen, Terapan dalam Manajemen Sistem Informasi, Andi Yogyakarta, 1996.

Fandy Tjiptono, Aplikasi Manajemen Kualitas, Usahawan, No. 11/TH.XXVII Nopember 1999.

Handoko, H. \& Tjiptono, F. Kepemimpinan Transformasional dan Manajemen Sumber Daya Manusia dalam Lingkungan Organisasi TQM, 1997.

Mulyadi, Total Quality Management, Universitas Gadjah Mada, Yogyakarta, 1998.

Robbins, Stephens, Organizational Behavior, Concepts * Controversies * Applications, Eighth Edition, 1998.

Sarwono, S.S. \& Sudarsono, J. Konsumen dan Total Quality Management, 1997.

Tampubolon, Daulat, P., Perguruan Tinggi Bermutu, Gramedia Pustaka Utama, Jakartam 2001.

Tjiptono, F. \& Diana, A. Total Quality Management, Edisi 2, Yogyakarta: Andi, 1996

Yudo Swasono, dkk., Manajemen Dalam Era Globalisasi, Elex Media Komputindo, Jakarta, 1997 
